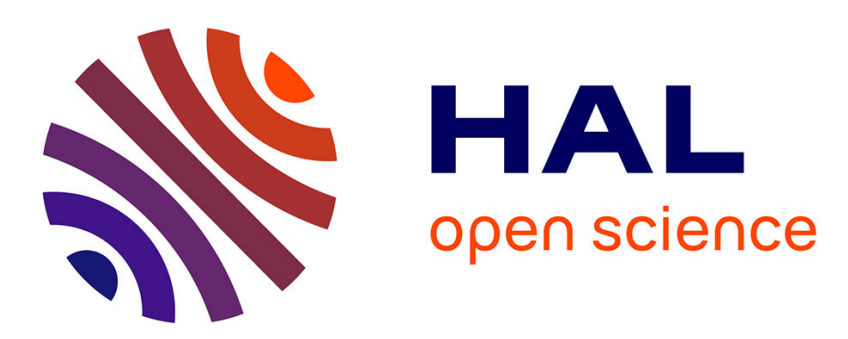

\title{
The origin and development of possibility in the creoles of Suriname
}

Bettina Migge, Donald Winford

\section{To cite this version:}

Bettina Migge, Donald Winford. The origin and development of possibility in the creoles of Suriname. R. Selbach, H. Cardoso, M. van den Berg Gradual creolization, John Benjamins, pp.129-153, 2009, 10.1075/cll.34.12mig . hal-01496555

\section{HAL Id: hal-01496555 https://hal.science/hal-01496555}

Submitted on 27 Mar 2017

HAL is a multi-disciplinary open access archive for the deposit and dissemination of scientific research documents, whether they are published or not. The documents may come from teaching and research institutions in France or abroad, or from public or private research centers.
L'archive ouverte pluridisciplinaire HAL, est destinée au dépôt et à la diffusion de documents scientifiques de niveau recherche, publiés ou non, émanant des établissements d'enseignement et de recherche français ou étrangers, des laboratoires publics ou privés. 


\section{Research Repository UCD}

Provided by the author(s) and University College Dublin Library in accordance with publisher policies. Please cite the published version when available.

\begin{tabular}{|c|l|}
\hline Title & $\begin{array}{l}\text { The origin and development of possibility in the creoles of } \\
\text { Suriname }\end{array}$ \\
\hline Author(s) & Migge, Bettina; Winford, Donald \\
\hline $\begin{array}{c}\text { Publication } \\
\text { date }\end{array}$ & $2009-05$ \\
\hline $\begin{array}{c}\text { Publication } \\
\text { information }\end{array}$ & $\begin{array}{l}\text { Selbach, R., Cardoso, H. and Van den Berg, M. (eds.). Gradual } \\
\text { Creolization: Studies Celebrating Jacques Arends }\end{array}$ \\
\hline $\begin{array}{c}\text { Publisher } \\
\text { Item }\end{array}$ & John Benjamins \\
\hline $\begin{array}{c}\text { record/more } \\
\text { information }\end{array}$ & http://hdl.handle.net/10197/6019 \\
\hline $\begin{array}{c}\text { Publisher's } \\
\text { version (DOI) }\end{array}$ & http://dx.doi.org/10.1075/cll.34.12mig \\
\hline
\end{tabular}

Downloaded 2017-03-21T19:36:48Z

The UCD community has made this article openly available. Please share how this access benefits you. Your story matters! (@ucd_oa)

Some rights reserved. For more information, please see the item record link above.

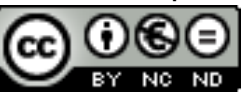




\title{
The origin and development of possibility in the creoles of Suriname ${ }^{1}$
}

\author{
Bettina Migge \\ University College Dublin \\ Donald Winford \\ The Ohio State University
}

In this paper we discuss the origin and development of the expression of possibility in the creoles of Suriname. We first describe the systems of possibility in Sranan and three Maroon creoles (Ndyuka, Pamaka, and Saamaka), drawing on data elicited from informants, conversational data as well as the published literature. We examine several modal elements, namely sa, kan, man, poy, whose distribution differs across the different varieties and also over time. Our analysis reveals that the system of possibility in Sranan is organized quite differently from that of the Maroon creoles. To explain these facts, we trace the development of this area of grammar by drawing on historical data from the early Sranan and Saamaka texts, and by exploring possible influence from the Gbe substrate languages as well as Dutch. We argue that the overall structure of this subsystem in the Maroon creoles was broadly modelled on Gbe while the rather different system found in Sranan Tongo is due primarily to influence from Dutch, and to internal

\footnotetext{
${ }^{1}$ Most of the data on the contemporary creoles of Suriname and on the Gbe varieties come from fieldwork conducted in Benin and Suriname between 2002-2004 as part of the project "The influence of West African Languages on the tense/mood/aspect (TMA) systems of two Surinamese creoles". We would like to hereby gratefully acknowledge the funding of the National Science Foundation (NSF Grant \#BCS-0113826). We would also like to thank informants in Benin and Suriname/French Guiana for generously giving their time and H. Capo, D. Gagnon, J. Essegbey and B. Sanna for helping with the collection of the data, and H. Capo, J. Essegbey and Enoch Aboh for insightful discussions about the interpretation of the Gbe data and Robby Morroy, Hertoch Linger, Margie McBean and Renata de Bies and Yolanda Boldewyn for insightful discussions of the Sranan Tongo data. Last but not least we also want to express many thanks to Laurence Goury for her help with the early documents. She had originally planned to co-write this paper to celebrate Jacques' contribution to the field of creole studies but was finally not able to do so for personal reasons. We also thank three anonymous reviewers and the editors of this volume for constructive criticism.
} 
developments.

Keywords: Possibility, Creoles of Suriname, contact-induced change

\section{Introduction}

The creoles of Suriname raise some intriguing questions concerning the interplay of internally and externally motivated language change in the formation and development of creole grammar. While the Surinamese creoles appear to descend from a common source, they still display noticeable differences that raise questions regarding their origins and developments that have not yet been fully explored. One subsystem that shows a fair amount of variation across the different Surinamese creoles is the expression of possibility. It involves four elements - sa, kan, man, poy - whose distribution varies across the different varieties and also over time. Moreover, the different elements do not appear to have emerged as the result of the same processes. This suggests that the development of this area of grammar represents an instance of gradualism in the emergence of the grammar of the creoles of Suriname (Arends and Bruyn 1995: 111; Arends 1993, 1999; Singler 1996, 1990).

In this paper we examine the expression of possibility in Sranan Tongo (henceforth Sranan) and the Maroon creoles (Ndyuka, Pamaka, and Saamaka), drawing on data elicited from informants, conversational data as well as the published literature. Our analysis reveals that the system of 
possibility in Sranan is organized quite differently from that of the Maroon creoles. The most striking difference has to do with the different meanings that the modal $s a$ conveys in the creoles. The Maroon creoles, (Pamaka, Ndyuka and Saamaka) employ this modal in a wider range of functions than Sranan does. For instance, Sranan distinguishes $s a$ from modal kan, which expresses both epistemic and deontic possibility, and also from mag (< Dutch mag), which expresses permissibility. By contrast, the Maroon creoles subsume all of these types of possibility under $s a$, suggesting that they employ this auxiliary as a marker of potential mood. To explain these facts, we trace the development of this area of grammar by drawing on historical data from the early Sranan and Saamaka texts, and by exploring possible influence from the Gbe substrate languages as well as Dutch. We argue that the overall structure of this subsystem in the Maroon creoles was broadly modelled on Gbe. On the other hand, we argue that the rather different system found in Sranan is due primarily to influence from Dutch, and to internal developments.

The paper is organized as follows. Section 1 compares the systems of possibility and the various modal elements that are used to express it in the contemporary creoles. Section 2 describes the distribution and uses of these elements in early Sranan and Saamaka documents, and compares them with their modern counterparts, with a view to determining similarities and differences in the expression of possibility. Section 3 
focuses on the influence of Dutch in the emergence of the Sranan system of possibility. Section 4 examines the uses of $s a$ in the early Sranan and Saamaka documents, while section 5 compares the uses of $s a$ in Sranan with the uses of Dutch zullen. Section 6 argues that the subsystem of possibility in the Maroon creoles, and the uses of $s a$ in particular, were heavily influenced by varieties of Gbe. The final section summarizes the findings and discusses their implications.

\section{Possibility in the modern creoles of Suriname}

Possibility includes notions such as ability, present likelihood, and permissibility, which respectively represent cases of dynamic, epistemic and deontic modality. Cases of dynamic modality simply assert what seems to be a factual statement, and do not involve the opinion or attitude of the speaker, except that the statement is true (Palmer 1986:102). Epistemic possibility "indicates the extent to which the speaker is committed to the truth of the proposition, for instance, when s/he conveys the sense that a proposition may possibly be true" (Bybee et al. 1994: 177). Finally, deontic possibility refers essentially to permission, which involves a deontic source that may be either the speaker or some other person or institution that creates the permission. 


\section{1. Dynamic possibility in the creoles of Suriname}

Dynamic possibility includes mental or learned ability and physical ability, as well as the broader concept of root possibility, which "is not restricted to the internal condition of ability, but also general external conditions" (Bybee et al 1994:178) .

All of the Surinamese creoles distinguish learned ability from physical ability. The former is expressed by a construction in which the verb sabi/sá 'to know' selects an activity verb. ${ }^{2}$

$\begin{array}{lllllll}\text { (1) a. } \mathrm{PM} / \mathrm{ND} / \mathrm{SN} & A & \text { pikin } & \text { ya, } & a & \text { sa(bi) leisi } & \text { bun. } \\ \text { b. SM } & \text { Di mii aki, } a \text { sá leisi bunu. } \\ & \\ & \text { DET child here she know read well } \\ \text { 'The/this child, it can read well/knows how to read well.' }\end{array}$

Physical ability is expressed differently in the four Creoles. In Saamaka it is always conveyed by the element $s a$, in both positive and negative contexts.

(3) a. SM Di muyEE $d E$ woyo án booko. A sa/ta si.

\footnotetext{
${ }^{2}$ In the Maroon Creoles, sabi also selects a small number of nouns that imply a certain activity, e.g. buku implies the activity of reading, to express mental ability (Migge 2006: $35)$.

${ }^{3}$ Unless otherwise indicated, the examples come from the authors' own field work.
} 
DET woman there eye NEG break. she MOD/IMPV see

'That woman is not blind. She can see/she sees.'

b. SM Di muyEE dE woyo booko. $A$ sa si.

DET woman there eye break. She-NEG POT see

'That woman is blind, she cannot see.'

Pamaka and Ndyuka use $s a$ (4) in positive contexts, but under negation physical ability is expressed by man in Pamaka and poy in Ndyuka (5).

(4) ND A taanga, a sa diki wan ondoo kilo.

She strong she MOD lift one hundred kilo

'She is strong, she can lift 100 kilos.'

(5)a. ND $A$ uman de beendi. $A$ á poy sii yu. DET uman there blind she NEG MOD see you 'That woman is blind. She cannot see you.'

b. PM $A$ uman de ain booko. $A$ án mansii $u$. DET woman there eye break she NEG MOD see you 'That woman is blind. She cannot see you.'

In certain restricted contexts such as in a (response to a) challenge, man and poy can also be used in positive contexts (cf. Migge 2006: 42). 
Sranan generally employs kan for positive physical ability and man for negative physical ability.

(6) a. SN A tranga srefisrefi. A kan opo wan hondro kilo. he strong selfself he can lift one hundred kilo 'He's really strong. He can lift a hundred kilos.'

b. SN A frow dati breni. A no man sii yu. DET woman that blind she NEG MOD see you 'That woman is blind. She can't see you.'

But, according to some Sranan speakers, kan does not indicate ability on the part of the agent, but rather possibility. For such speakers, man is increasingly being used in both positive and negative contexts to express ability. As one Sranan informant notes, kan implies a choice or opportunity to do something, while man means one has the ability to do it. Hence the contrast between the following sentences:

(7) a. SN $A$ boy kan waka go na foto. DET boy MOD walk go LOC town 'The boy can (i.e. has the choice to) walk to town.' 
b. SN [Context: Speaker was ill before, but has recovered

sufficiently to play a game of football]

Tide mi man prei baka, mi e feri betre.

Today I MOD play again I IMP feel better

'Today I can, (i.e. am able to) play again, I'm feeling better.'

\section{2. Root possibility in the creoles of Suriname}

The Maroon creoles employ the same elements that are used to express ability to convey more general types of root possibility. Saamaka employs $s a$ in both positive and negative contexts and Pamaka and Ndyuka use $s a$ in positive contexts and man and poy, respectively, in negative contexts.

(8) a. SM Mi a(bi) moni, nou mi sa go a booko di dia.

I have money now I MOD go LOC break DET day

'I have money thus I can go to the party.'

b. SM Mé sa ko tide moo mi fii siki tide.

I-NEG MOD come today more I feel sick today

'I'm not able to come today because I am feeling sick.' 
(9) a. ND Mi a(bi) moni, mi sa go na a fesa.

I have money I MOD go LOC DET party

'I have money, thus I can go to the party.'

b. ND Mi á poy de na a kiiman se.

I NEG MOD exist LOC DET killer side

'I can't be on the killers side.'

Sranan speakers generally employ kan to express this meaning in the positive, and man in the negative, as in the case of ability.

(10) a. SN Mi abi moni, dati meki mi kan gona a dansi.

I have money that make I can go LOC DET dance

'I have money, so I can go to the dance.'

b. SN Mi no abi moni, dati (ede) meki mi no man go

I NEG have money that head makeI NEG MOD go na a dansi.

LOC DET dance

'I don't have money, so I can't go to the dance.'

However, some speakers use kan instead of man in negative contexts. One informant notes that kan may be used if a reason is given. 


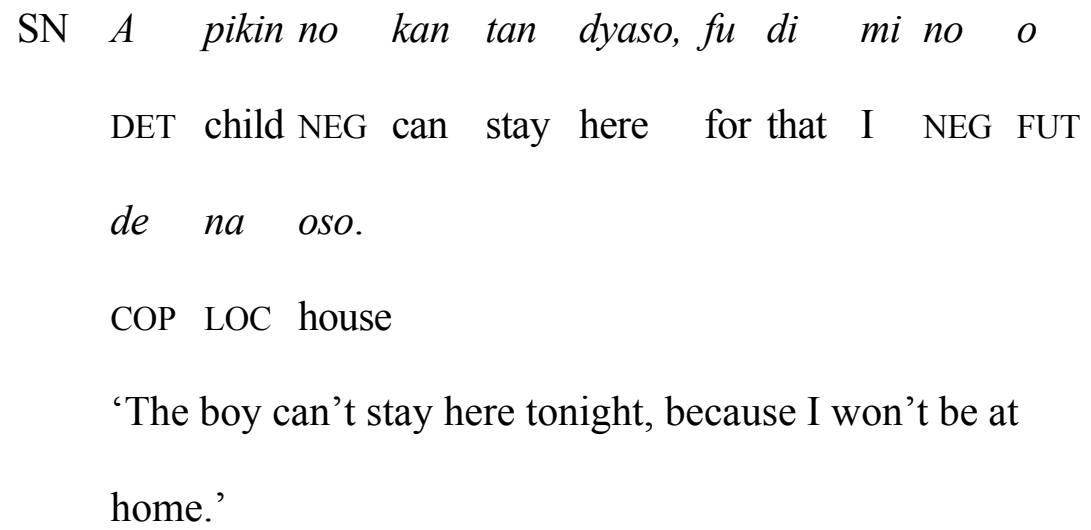

This use of kan does not imply that there is a prohibition on the agent's actual ability to perform the act, but simply that the possibility does not exist. These data suggest that some Sranan speakers are keeping physical ability separate from (other kinds of) root possibility.

\section{3. Deontic possibility in the creoles of Suriname}

Deontic possibility or permission is expressed in the same way as ability and root possibility in the Maroon Creoles: $s a$ is used in positive constructions and man/poy in negative constructions in Pamaka and Ndyuka, while Saamaka employs $s a$ in both kinds of construction.

(12) a. PM $A$ boy sa tan ya f'en tide neti. DET boy MOD stay here for-him today night 'The boy can (i.e. is allowed to) stay here tonight.' 
b. PM $A$ boy án man tan ya tide neti.

DET boy NEG MOD stay here todaynight

'The boy cannot (i.e. is not allowed to) stay here tonight.'

(13) a. SM Eside ndeti mi mma taami sa go ku en Yesterday night my mother tell I MOD go with her a foto.

LOC town

'Yesterday night, my mother said I can go with her to town.'

b. SM Yee $i$ á ta libi bunu, $i$ á sa pee

If you NEG IMF live well you NEG MOD play

$k u$ di oto wan fi $i$.

with DET other one for you

'If you aren't nice, you won't be allowed to play with the others.'

In Sranan, permissibility is expressed by kan in the positive and man in the negative but the Dutch-derived element mag is increasingly used in both contexts as well.

(14) a. SN $A$ boy $\mathrm{kan} / \mathrm{mag}$ tan dyaso tide neti.

DET boy MOD/MOD stay here today night 
'The boy may (is allowed to) stay here tonight.'

b. SN $A$ pikin no o man/mag tan dyaso tide neti. DET child NEG FUT MOD stay here today night A no kisi primisi. he NEG get permission 'The child cannot stay here tonight. He did not get permission'

\section{4. Epistemic possibility in the creoles of Suriname}

Epistemic possibility is expressed by modal auxiliaries as well as by adverbials like kande (< kan + de 'can be') 'maybe,' and expressions like $A \mathrm{kan} / \mathrm{sa}$ de taki 'it may be that.' The latter two choices are more typical of Sranan and the Eastern Maroen creoles.Not true, see data on SM: OMIT In the Maroon Creoles, kande and $s a$ are both used in positive and negative contexts.

(15) a. ND Den pikin sa e siibi nounou. DET-pl child MOD IMF sleep nownow

b. SM Dee mii dee sa ta duuminounou. DET-pl child they MOD IMF sleep nownow

c. ND Kande den pikin (sa) e siibi nounou. Maybe DET-pl child MOD PROG sleep nownow 
'The children may be sleeping now.'

(16) a. PM Kande den pikin ná o siibi nounou. Maybe DET-pl child NEG FUT sleep nownow 'Maybe the children won't be sleeping now.'

b. PM J. án sa de a osu nounou.

J. NEG MOD COP LOC house nownow

'J. may not be at home right now.'

In the negative, constructions with kande appear to be preferred in Pamaka and Ndyuka though.

Sranan, on the other hand, prefers to use expressions like kande and a kan (de) taki in all contexts.

(17) a. SN Kande den pikin (no) e sribi kaba.

Maybe DET-PL child (NEG) IMPV sleep COMPL

'The children may (not) be sleeping already'

b. SN A kan (de) taki alen o kon tide neti.

It MOD COP that rain FUT come today night

'It may rain tonight (= It's possible it will rain tonight)' 
Some Sranan speakers seem to employ the modal auxiliary kan to convey epistemic possibility, but this appears to be quite rare. Only one of our informants allowed for the following:

(18) SN John kan de na oso nownow.
John MOD be-there LOC house nownow
'John may be at home now.'

It must be noted that Sranan also uses $s a$ in an epistemic function, as in the following sentence:

(19) $\mathrm{SN}$

Jan sa de na oso nou(nou).
John MOD be-at LOC house nownow
'John should be at home now (i.e. it's probable that John is at
home now).'

This at first glance suggests that Sranan uses $s a$ in the same way as the Maroon creoles. But Winford (to appear) demonstrates that the epistemic sense of $s a$ in Sranan is somewhat different from that in its sister creoles. In the former, $s a$ conveys the speaker's assessment of the probability of a situation being true, based on her/his assumptions, expectations and weighing of options in relation to the situation in question. This is in fact 
quite close to the epistemic use of English must, that is, the sense of strong probability. Closely related to this is the use of $s a$ in assertions like the following which express strong expectation on the speaker's part:

[Context: John's father has died in Holland, and John is in Suriname. He hates flying, but still:]

(20) SN Fu di na en p’pa dede, a sa go na p'tata.

For that FOC his father dead he MOD go LOC Holland

'Since it's his father that died, he shall/should go to Holland.'

In such cases, $s a$ conveys the sense that the other person will perform the future action because he is under some kind of moral or social obligation to do so. By contrast, in the Maroon Creoles, the informants always insisted that $s a$ in cases like these always expresses possibility, and never claimed that it could convey strong probability or the sense of an obligation. ${ }^{4}$ The similarities between the Maroon creoles and Sranan in relation to the use of $s a$, then, are limited, or partial. We discuss the use of $s a$ in Sranan in more detail in section 5.

\section{5. Summary of the findings}

${ }^{4}$ In the Maroon creoles obligation is expressed by $m u$ or $m u s u(f u)$. 
To sum up, several differences are found among the Creoles. Saamaka employs $s a$ to express all forms of possibility, including ability, root possibility, permissibility and epistemic possibility, in both positive and negative contexts. Ndyuka and Pamaka, on the other hand, use $s a$ to express all these notions in positive contexts, but employ poy and man, respectively, in negative constructions, as well as in a few positive constructions involving physical ability. We suggest that, in the Maroon creoles, all types of possibility are subsumed under a category of Potential mood, expressed by $s a$. This accords with previous analyses in the literature. Thus, Huttar and Huttar (1994:513) describe $s a$ in Ndyuka as conveying intention, uncertainty and potential mood, that is, the sense of 'be able.' Similarly, Rountree (1992:44) describes $s a$ in Saamaka as meaning 'may, might, can', and says it indicates possibility or ability. The various interpretations of $s a$ as expressing a particular type of possibility are largely dependent on the discourse context. We further suggest that, in Ndyuka and Pamaka, poy and man respectively convey dynamic and deontic possibility in negative contexts. It may be reasonable to say that their core meaning is ability. Finally, in Sranan, we can identify at least three distinct modals of possibility, kan for root possibility, man for physical ability, and mag for permission. Epistemic possibility is generally expressed by adverbial kande or the expression $A$ kan de taki, and not by a modal, though some speakers appear to use kan in this sense. But changes 
seem to be in progress in Sranan that appear to be leading towards making man the marker of physical ability, kan the marker of possibility and mag the marker of permission in both negative and positive contexts. In addition, Sranan differs from the Maroon creoles in that it uses $s a$ to convey the sense of probability, and in some contexts, expectation or obligation.

The differences among the creoles raise two sets of questions. First, have these differences always been present or did they emerge later, as each creole evolved separately? If they emerged later, what was the original system like? Second, what are the reasons for the differences in the modern systems? Did they come about due to different kinds of input, different kinds of contact-induced changes and/or different kinds of language-internal changes?

In the next section, we investigate the ways in which the various modal elements surveyed above are used in the early Surinamese creole texts, in order to determine whether their functions there are similar to those found in the modern creoles.

\section{The uses of the modals of possibility in the early documents}

Our investigation is necessarily limited to earlier Sranan and Saamaka, since no early documents are available for the Eastern Maroon 
varieties Pamaka and Ndyuka. While there are a few documents from the late $17^{\text {th }}$ century, e.g., court records (van den Berg 2000), and early $18^{\text {th }}$ century, e.g., the Herlein fragment of 1718 , most of the linguistically substantial documents date from the mid to late $18^{\text {th }}$ century, that is at least 70 years after the projected emergence of the early plantation varieties in the later $17^{\text {th }}$ century. ${ }^{5}$ Most of these documents were written by Europeans whose exposure to the language and its different varieties varied. For discussions of the background of the authors see Arends (1995), Bruyn (1995), van den Berg (2007).

Our investigation of the early documents from Sranan and Saamaka reveals similarities to, as well as some important differences from, the modern varieties. The most significant difference concerns the modal $s a$, which is used in the early texts primarily to express futurity and related modal notions to be discussed below, but is not used to convey possibility, as far as we can tell. In general, possibility seems to be expressed primarily by kan in both early Sranan and Saamaka. We will discuss the expression of possibility in the following section, and then consider the uses of $s a$.

\footnotetext{
${ }^{5}$ The historical data for Sranan come from the following sources: the Court Records from 1667 until 1767 (in van den Berg 2000); Herlein 1718, van Dyk c1765, Nepveu 1770 (in Arends and Perl 1995); the Saramaccan Peace Treaty in Sranan (1762) (Arends 2004 and van den Berg 2004); Schumann's dictionary of Sranan (1783) (Kramp 1983); the NegerEngelsch - Nederlands Woordenboek from Focke 1855. The historical data for Saamaka come from a Saramaka dictionary and grammatical sketch by Riemer (1779) (in Arends and Perl 1995), Schuchardt's edition of Wietz' edition of Schumann's Saamaka dictionary (1778), the translation of the story of the Apostles by Wietz 1805 (in Schuchardt 1914) and the Saamaka Maroon Letters (Arends and Perl 1995).
} 


\section{1. Possibility in the early Sranan Tongo texts}

All of the modern modals, kan, man and, more rarely mag, can be found in the early Sranan texts. Kan and mag are used in much the same way as in modern Sranan, while man functions more like a noun, though it is clearly the source of the modern modal.

Kan closely resembles both the English modal can and the singular form of its Dutch counterpart, kunnen (Cf: ik kan, jij kan, zij/hij kan 'I/you/she/he can'), suggesting that it originally derived from either one or possibly from both of them. In the early Sranan texts kan is used in ways quite similar to its modern counterpart, to express root possibility (21a), (physical) ability (21b) and permission (21c).

(21) a. ESN lange monni mi kan kissi alle zanti na engelsze konderi. with money I MOD get all thing LOC English country 'I can get anything with money in England.'

(Van Dyk c1765 in Arends and Perl 1995: 153)

b. ESN mi no ha tiffi morro, mi no kann kau.

I NEG have teeth more I NEG MOD chew

'I don't have any teeth anymore, I cannot chew.'

(Schumann 1783 in Kramp 1983: 150)

c. ESN Da misi takki offe mastra plessi a kan go 
DET lady say if master please he MOD go

lange da boto.

PREP DET boat

'The lady says you can go on [with] her boat.'

(Van Dyk c1765 in Arends and Perl 1995: 214)

Kan is also used in the same meanings in negative contexts (22b), where man would be expected in modern Sranan. The use of man (also spelt mann) to express ability is first attested in the court records in 1707 (Van den Berg 2007: 215). It is also attested in Schumann's 1783 Sranan dictionary where it also expresses negative physical ability but selects a non-finite VP headed by the preposition va (22).

(22) ESN Mi no man va hoppo datti.

I NEG man for lift that

'I am not strong enough to lift that (lit.: I am not man for lift that).'

'I cannot lift that.'

(Schumann 1783: 107 cited in van den Berg 2007: 216).

In (22) man is a noun meaning '(male) person'. The modern modal auxiliary emerged from this noun due to a process of reanalysis and grammaticalization, and substrate influence (Van den Berg 2001, Van den 
Berg and Arends 2004, Migge 2006). Modal man is not attested in either early or modern Saamaka.

Mag also appears, though rarely, to express permission in early Sranan.

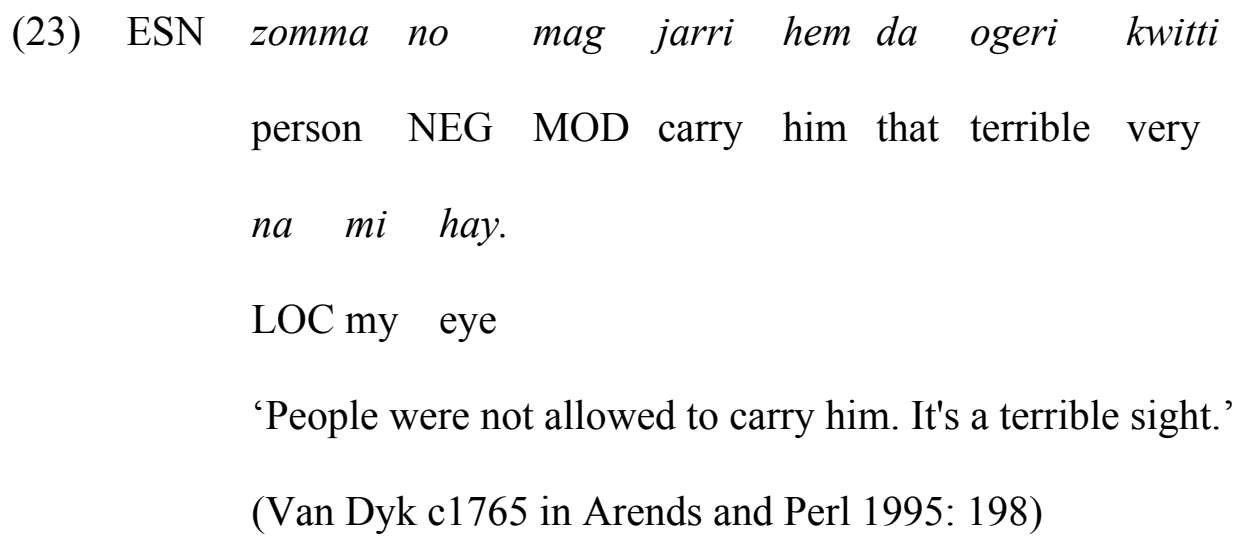

We found no examples of kan being used to express epistemic possibility, but instances of this are rare in the early texts anyway WHAT'S YOUR REFERENCE?, so no firm conclusion can be drawn. However, the adverb zomtem 'perhaps' is sometimes used, with $s a$, to express possibility (see below). This parallels the use of kande (in combination with future $o$ and $s a$ ) in modern Sranan. In general, then, the system of possibility in early Sranan is quite similar to what it is in modern Sranan.

2.2. Possibility in the early Saamaka documents. 
In early Saamaka, only kan and poli, the reflex of modern poy, are attested. Kan is not attested in the Saamaka dictionaries, but we found one example in Wietz' translation of the gospel and four instances of kan in the Maroon Letters from Saamaka. They express ability (24a) and root possibility (24b).

(24) a. Joe no sabbi da moeffe va mi bieka joe no you NEG know DET mouth for me because you NEG kan jerri gweette gweet. can hear at.all at.all 'And you don't know my language becaue you can't understand it at all.'

b. na hem ala somma kan findi boene liebi va teh go. in him all person can find good life for until go 'In Him everybody can find eternal life.'

(Maroon Letters from Saramaka 1790 in Arends and Perl 1995: 286) Kan is not used in the modern Maroon Creoles. ${ }^{6}$

The modal poy derives from the earlier form, poli, which in turn derives from pode [podi] 's/he can,' the third person singular form of the Portuguese verb poder 'can' (Smith 1987). In the examples attested in

${ }^{6}$ Our conversational and elicited data from the Maroon creoles suggest that kan is not generally used in the contemporary Maroon creoles outside of cases of code-mixing and codeswitching with Sranan (cf. Migge 2007) and the phrases $a$ (no) kan taki... 'It is (not) possible that...'. 
Schuchardt's edition of Schumann's 1778 Saamaka dictionary and in Wietz' translation of the gospel poli conveys a sense of ability.

(25) a. ESMwi no poli va brokko di tranga watra aki. we NEG can PREP break DET strong water here 'We cannot fight against the current here.' (Schumann 1778 in Schuchardt 1914: 57)

In most examples it occurs together with the negative marker and selects a non-finite VP headed by the preposition va. However, there is one example in Wietz where it is used without the negation marker and another one in which $v a$ is absent (cf. Wietz 1805: Schuchardt 1914: 29, 16). Poli is not used in modern Saamaka, but, as we have seen, its modern form, the modal verb poy, conveys ability in negative contexts in modern Ndyuka.

\section{3. Summary}

To sum up, both early Sranan and Saamaka express possibility with the modal kan and other elements such as mag (Sranan) and poli (Saamaka). $S a$, as far as we can tell, is not part of the system of possibility in the early documents. We also found clear continuities between early and modern Sranan in the use of the modals of possibility. By contrast, the 
system represented in the early Saamaka texts differs sharply from that of modern Saamaka, where $s a$ is the primary means of expressing possibility. In the following sections, we attempt to explain the different developments in the expression of possibility across the contemporary creoles. First, we argue that the modern Sranan system of possibility, centered around modals kan and mag, is modelled largely on that of Dutch, with the exception of modal man, which is due to both substrate influence and internal developments. Second, we attempt to explain the significant differences between Sranan and the Maroon creoles in their use of the modal $s a$. We argue that the uses of $s a$ in both early and modern Sranan have been strongly influenced by the uses of Dutch zullen 'shall, should.' On the other hand, we argue that the use of $s a$ as a marker of Potential mood in the contemporary Maroon creoles may have been due to the influence of Gbe languages, which had markers of Potential mood with uses similar to those found in the Maroon Creoles.

\section{Dutch influence on possibility in Sranan.}

Most of the uses of kan attested in the early Sranan texts are identical to those found in contemporary Sranan. The meanings it conveys in both forms of the language include root possibility, ability and permission. Its use to convey epistemic possibility is marginal at best in modern Sranan, and seems to be a recent development. The various uses of kan are very 
similar to those of kunnen in Dutch, as illustrated in the following examples, taken from van Dyk's (1765) early Dutch (EDU) translations of early Sranan.

First, kunnen expresses root possibility, including ability in both languages.

\author{
a. ESN Mastra da homan no kan wakke \\ master the woman NEG can walk \\ rasi brokke kwetti. \\ buttocks break quite \\ b. EDU Meester dat Vrouws-Perzoon kan niet loopen, \\ master that woman-person can not walk \\ haar Billen binnen stukkend. \\ her buttock in pieces \\ 'The woman can't walk, master. Her buttocks are \\ completely ruined.'
}

(Van Dyk 1765, in Arends and Perl 1995: 179)

Second, kunnen also conveys the notion of permission (compare 21c).

(27) EDU De Jufvrouw zeid als het myn Heer
DET lady say if it my master
geleegen komt zoo kan hy meê gaan.


suit come so can he with go

'The lady says if it suits my master he can come along.'

(Van Dyk 1765, in Arends and Perl 1995: 214)

Third, in modern Dutch, and presumably also in early Dutch, kunnen expresses the notion of epistemic possibility.

$$
\begin{aligned}
& \text { Jan kan wel verhinderd zijn. } \\
& \text { name can surely obstructed be } \\
& \text { 'Jan may be held up.' (Coppen et al. 2004: 18·5·4·4·ii·a, ex. 1) }
\end{aligned}
$$

The close similarities in meaning and function between kan in Sranan and kunnen in Dutch suggest that the former was modelled on the latter.

However, given that the main superstrate input to the creoles of Suriname, English, has a phonetically and semantically similar form, can, it is equally likely that the meanings of kan initially emerged due to influence from English and were subsequently only reinforced by Dutch influence. Finally, we saw that, in early Sranan, permission could also be expressed by mag, which is clearly a borrowing from Dutch, compare (23) with its translation (29b) and (29a).

(29) a. DU Je mag hier niet roken. You MOD here NEG smoke 
'You are not allowed to smoke here.'

(Coppen et al. 2004: 18·5·4·4·iii $\cdot$, ex. 36)

b. EDU ...Mogthy niet door Menschen

MOD he NEG through people

Begraaven worden.

bury $\quad ? ? ?$

'... was he not allowed to be buried by people/humans.'

(Van Dyk 1765, in Arends and Perl 1995: 198)

\section{4. $\quad S a$ in the early texts}

We now examine the use of $s a$ in the early texts and compare them with its use in the modern varieties. Our examination reveals that $s a$ is used in quite similar ways in early Sranan and Saamaka. It's primary use is to express futurity, though it also conveys certain modal notions. In the early Sranan (ESN) texts, $s a$ is spelt variously as zal, zel, za, ze, zey, zoe, saa, sal and $s a$ (van den Berg 2007: 199). ${ }^{7}$ It appears mostly as $s a$ in the early Saamaka documents. Recent analyses (Winford to appear, Migge and Goury in press) suggest that it derives from zal, the first and third person singular form of the Dutch auxiliary zullen 'must', but others link it also to English shall (cf. Van den Berg 2007: 188).

\footnotetext{
${ }^{7}$ In the text we will continue to use $s a$ to refer to these orthographic variants, but the textual examples will, of course, preserve the original orthographic variant.
} 
In the early Sranan and Saamaka texts, $s a$ expresses future time reference in contexts specially marked for future time reference (30a and b) and in constructions that lack such overt reference (31a and b). ${ }^{8}$

(30) a. ESN Pikien morre wi za drinki koffi.

small more we FUT drink coffee

'We'll drink coffee in a few moments/a little while.'

(Van Dyk c1765 in Arends and Perl 1995: 150)

b. ESMmi bribi, tide bakkraman sa doro.

I believe today European.person FUT arrive

'I believe that the people of Paramaribo will come back

today.' (Schumann 1778 in Schuchardt 1914: 61)

(31) a. ESN Ke joe za habi plyziri noeffe.

INTERJ you FUT have pleasure enough

'You'll have a lot of fun.'

(Van Dyk c1765 in Arends and Perl 1995: 144)

b. ESMju sa poli tulle sanni.

you FUT spoil all things

'You will spoil everything.'

(Schumann 1778 in Schuchardt 1914: 97)

\footnotetext{
${ }^{8}$ In the former contexts sa appears to be optional (cf. Van den Berg 2007: 188-9).
} 
Van den Berg (2007:188) confirms that later time reference is expressed by (variants of) the preverbal marker $s a$, and/or by temporal adverbs denoting later time reference, in all of the early Sranan sources.

$\mathrm{Sa}$ also conveys certain modal overtones, such as commitment or intention on the part of the speaker, or the sense of weak obligation or requirement. We regard these as secondary meanings of $s a$, which are contextually determined. Commitment typically takes the form of a promise (32) or a threat (33):

(32) a. ESN Mastratanki fo joe mino zal doe morre. master thanks for you I.NEG MOD do more 'Please, master, (I promise) I won't do it again.' (Van Dyk c1765 in Arends and Perl 1995: 179)

b. ESM teh mi go na plantasi, mi sa komm lukuju wanten. when I go LOC plantation I MOD come look you one.time 'When I go to the field/plantation, I'll come to see you as well.' (Schumann 1778 in Schuchardt 1914: 113)

(33) a. ESN a doe wan trom morre mi za kiele da homan. she do one time more I MOD kill the woman 'If she does it one more time, I shall kill the woman.' (Van Dyk c1765 in Arends and Perl 1995: 179) 
b. ESMMi sa da yu kangra.

I MOD give you kangra

'I will/shall use the kangra method to determine whether or not you are guilty (of some crime).' (Schumann 1778 in

Schuchardt 1914: 76)

In both early Saamaka and Sranan we also find uses of $s a$ where it seems to express a sense of weak obligation or requirement.

(34) a. ESMmi sa go jusnu?

I MOD go just now

'Should I go immediately?'

(Riemer 1779 in Arends and Perl 1995: 341)

b. ESN Da bassia takki mi za go na mastra

DET manager say I MOD go LOC master

fo locke koekeroe worke.

for look kitchen work

'The manager said that I should go to the master to do work in the kitchen.'

(Van Dyk c1765 in Arends and Perl 1995: 185) 
These findings are in keeping with the views expressed by Schumann (1783:146), who observes that, in early Sranan, $s a$ conveys future time reference, as well as the sense of (German) sollen 'shall, should.' With regard to earlier Saamaka, however, Schumann and, following him, Riemer sugggest that sa means only: sollen (Perles translation of Riemer 1779 in Arends and Perl 1995:374).

The early documents also show that, by the late $18^{\text {th }}$ century, the motion verb go, usually in combination with progressive markers de (Sranan) and tan (Saamaka) had emerged as a means of conveying futurity, thus entering into competition with $s a$.

(35) a. ESN a de go passa abra. he IMF go pass over 'It will/is going to overflow.' (Schumann 1783 in Kramp 1983: 45)

b. ESN Mi go meki brifi.

I FUT make letter

'I'll/am going to write a letter.'

(Schumann 1783 in Kramp 1983: 69)

(36) ESM mi tann go worko.

I IMF go work

'I will work.' (Riemer 1779 in Arends and Perl 
The future marker $o$ in the contemporary creoles most likely developed from (de/tan) go via a cross-linguistically well-attested path of grammaticalization (Bybee and al. 1994) and phonological reduction (Migge and Goury in press).

The emergence of this new future marker as a competitor to $s a$ is quite relevant to our discussion, since it may explain why sa gradually became associated less with the temporal notion of later time reference, and more with the modal meanings it now conveys. Van den Berg (2007: 192) suggests that (de) go expressed predictive future, prospective future, and intention. She also suggests that (de) go conveyed a greater degree of commitment to the truth, while $s a$ became associated with overtones of uncertainty (p. 193-4).

With regard to early Saamaka, Schumann, and following him, Reimer, provide some insight into the difference between the competing markers of futurity. They argue that $\tan +\mathrm{go}$ is the main or common future-marking strategy in $18^{\text {th }}$ century Saamaka. Riemer also notes that “...sa can be used instead of tanngo, e.g. mi sa go, mi sa worko; but actually $\boldsymbol{s} \boldsymbol{a}$ in this case is Town-language (Sranan), because in Saramaccan it means only: sollen [German: 'shall, should']." (Perl's translation of Riemer 1779 in Arends and Perl 1995:374). 
This suggests that the use of $s a$ as a marker of later time reference survived somewhat later in early Sranan than in Saamaka. If so, it might be attributed to Dutch influence. Van den Berg (2007:196) suggests that "sa expressing predictive and prospective future may have been more common in (late $18^{\text {th }}$ century) bakratongo, whereas the construction de go conveying these notions may have been associated with (late $18^{\text {th }}$ century) ningretongo.

She cites the following examples from Schumann's dictionary (glosses and translations are hers).

(37) a. da gotro sa kalfe. (bakratongo) DET trench FUT collapse 'The trench will/is going to collapse.' b. da gotro de go brokko. (ningretongo) the trench ASP FUT break 'The trench is going to collapse.' (Schumann 1783: 78)

Unfortunately, Schumann himself provides no translations of these sentences, nor explanation of what sa meant in ningretongo, since we have to assume it was also used in that variety. Whatever the facts might have 
been, it is at least clear that there was a growing distinction between $s a$ and de/tan go in later $18^{\text {th }}$ century Sranan and Saamaka. Moreover, as we saw, $s a$ developed very different meanings in the two creoles. In the following sections, we attempt to explain the differences in term of stronger and continuing Dutch influence on the use of $s a$ in Sranan, and stronger Gbe influence on its use in the Maroon creoles.

\section{Dutch influence on sa in Sranan}

We suggested earlier that $s a$ derives from Dutch zullen, though English shall cannot be ruled out as an alternative source. The meanings and uses of $s a$ in modern Sranan in many respects parallel those of its Dutch (and/or English) source. Both can be used to convey dynamic, epistemic and deontic modality.

When used to refer to future events, both $s a$ and zullen express dynamic modality, that is, they express what seems to be a factual statement that does not involve the attitude or opinion of the speaker (Palmer 1986:102). In cases where the speaker is the agent of the future action, they both convey commitment, which may be construed either as a promise (38), or a threat (39), depending on the circumstances.

(38) a. SN Efu yu kon tide neti, mi sa gi yu 
if you come today night I MOD give you

a moni, yere.

DET money hear

'If you come tonight, I shall pay you the money, okay?'

b. DU Als je vanavond komt zal ik je het when you tonight come shall I you the geld betalen.

money pay

'If you come tonight, I shall pay you the money.'

(A. Bryun personal communication August 2007)

(39) a. SN Efu yu no gi mi a moni, if you NEG give me DET money

mi sa fon $y u$.

I MOD beat you

'If you don't give me the money, I shall beat you.'

b. DU Als je me niet betaalt zal ik je

when you me not pay shall I you

in elkaar slaan.

in each.other beat

'If you don't pay me, I shall beat you up.'

(A. Bryun personal communication August 2007)

In cases where someone other than the speaker is the agent of the action, $s a$ and zullen convey a sense of expectation on the speaker's part that the event will occur. 
(40) a. SN Mi p’pa sa yepi yu.

my father MOD help you

b. DU Mijn vader zal je helpen.

my father MOD you help

'My father will help you.'

(Wendelaar and Koefed 1988:68)

There also seems to be some sense, at least in Sranan, that the agent is under some obligation to act. This may be related to the fact that zullen, like its counterparts in other Germanic languages (English shall, German sollen, Scandinavian $s k$ ), originally conveyed obligation, and that modal sense still underlies its use today.

This undertone of obligation is also relevant to the fact that both $s a$ and zullen can be used in both epistemic and deontic senses, to convey probability and requirement (a command) respectively. ${ }^{9}$ The former use is illustrated in the following examples:

a. SN Den pikin sa $e \quad$ sribi now(now).

DET-pl child MOD IMPFV sleep now

'The children should be sleeping now.' (=it's very likely they are).

b. DU De kinderen zullen nu wel slapen.

DET children should now surely sleep

\footnotetext{
${ }^{9}$ Though we found no clear examples of the epistemic and deontic uses of $s a$ in the early Sranan documents, this does not necessarily mean that they did not exist at the time.
} 
'The children should be sleeping now.'

(Margot van den Berg, pc April 2008)

This use of present forms of zullen to express probabilty in Modern Dutch seems to be somewhat archaic. Generally, speakers seem to prefer to use a past form of zullen e.g, zoud(en) 'should' or the modal moet CHECK in this function (Margot van den Berg, pc, April 2008).

Finally, in certain contexts, both $s a$ and zullen have deontic force, and convey the sense of a command, as in the following:

(42) a. SN $A$ pikin sa tan dya tide neti.

DET child MOD stay here today night

b. DU De jongenzal vanacht hier blijven.

DET boy MOD tonight here remain

'The boy shall stay here tonight.' (= I'll see that he does).

(Margot van den Berg, pc April 2008)

(43) a. SN Alen sa kon tide neti.

rain MOD come today night

b. DU Het zal vanavond regenen.

it MOD tonight rain

'It shall rain tonight' (= I command it to rain). 
It is interesting that a Sranan and Dutch informant both expressed the view that $s a$ seems odd here, since no one can command the weather, except God, as the Sranan informant noted.

To sum up, the use of $s a$ to express dynamic modality in modern Sranan parallels its use in early Sranan, though it may have lost its earlier temporal character. The other uses of $s a$ in contemporary Sranan, to express epistemic and deontic modality, may have developed more recently, though we cannot be sure that they did not exist in early Sranan. Finally, all three modal meanings of $s a$ in modern Sranan seem to have been modeled on the meanings of zullen.

\section{Gbe Inflence on possibility in the Maroon Creoles.}

We argue in this section that the system of possibility in the Maroon creoles was shaped primarily by influence from Gbe languages. This explains the use of $s a$ in these creoles, as well as several other strategies they use to express possibility. Some of the latter strategies are also found in Sranan.

\subsection{Gbe influence on sa.}


We offer two possible scenarios that might explain how substrate influence shaped the meanings and uses of $s a$ in the Maroon creoles. According to one scenario, argued for in Winford and Migge (2007), the broad use of $s a$ in the Maroon creoles is modelled closely on the potential future marker found in Western Gbe languages. Several Gbe varieties, e.g., Ewegbe varieties such as Wacigbe and Anlogbe, as well as Xwelagbe and Xwlagbe, employ a marker of futurity $(l a ́, a ́)$ which can be used to express notions such as epistemic possibility, root possibility, permissibility, and so on. Essegby (to appear) argues that these markers convey the sense of potential mood in Ewe. For instance, $(l) \grave{a}$ can be used with stative predicates to refer to a possible state of affairs in the present:
(44) Anlo
Ilevi-a-wo A\$-NO
alOdO-m
fifia

child-DEF-PL POT-AUX:NPRES sleep sleep-PROG now

'The children may be sleeping now.'

It may also be used to refer to a future possibility:

(45) Anlo

m-a-Ãu a!-yi fofo!-nye gbO!

1SG-POT POT-go father-1SG place

'I may move to my father's place.'

(Essegby to appear:16)

Third, the Potential marker can also be used to convey the sense that it is possible for someone to do something:

(46) Anlo á-xlé agba-lê mábbeee (2004 p. 10) 
you-POT-read book that easily

'You can read that book easily.'

In this case, Essegby comments that "this sentence does not make predictions about a state of affairs to come. Instead, it suggests that the addressee is in a position to read the book without difficulty" (To appear, p. 11). Our elicited data also contain examples in which notions like ability (47), and permissibility (48) are expressed by (l)a or its cognates.

(47) Wací '! s’N NtO ya! k0 kilo ka!v' kuwu'i! he strong very he-FUT lift kilo $40 \times 2+20$

'He is very strong; he can lift a hundred kilos.'

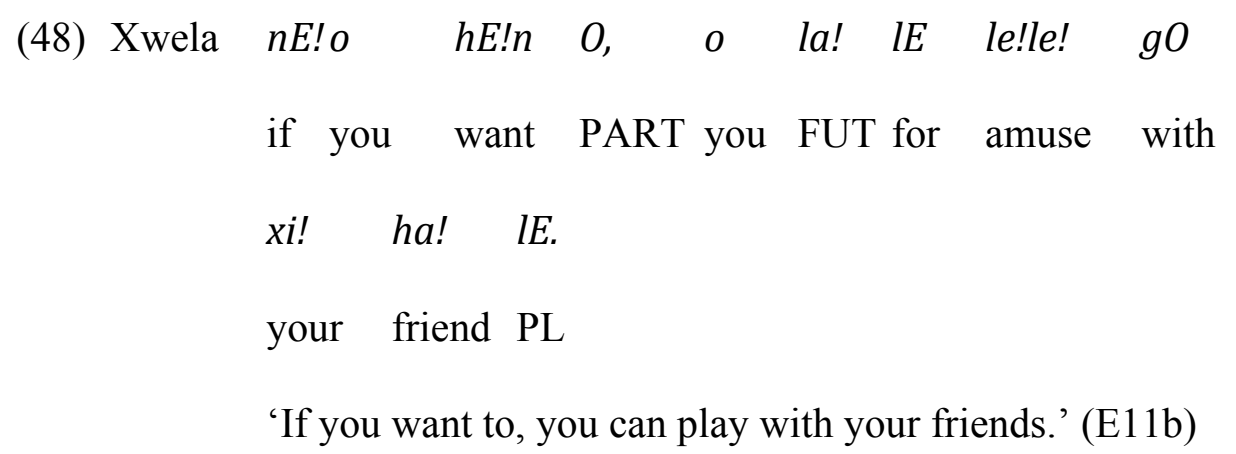

This range of meanings closely resembles that expressed by $s a$ in the Maroon Creoles. In all these cases, what seems to be expressed by the modal auxiliary is the sense of something that is possible, or a potential 
situation - a sense which may be interpreted in the various ways described above. These similarities suggest that $s a$ in the Maroon creoles might have been modelled after the Potential future marker of Western Gbe varieties.

An alternative scenario to explain substrate influence on the expression of possibility in the Maroon creoles is offered in Migge (2006). She argues that $s a$ is modelled on the Gbe modals of possibility like teyu, tip, ten, sixu, etc, which express a range of meanings quite similar to that of $s a$ in the Maroon Creoles, including physical ability (49), root possibility (50), permission (51), and epistemic possibility (52).

(49) Xwla e jO asu. e tEn kO kilo kOnwewi. he be man he MOD lift kilo 100 'He is very strong, i.e. acts like a man. He can lift 100 kilos.'

(50) Xwla e tEn luter na EmE-bu ya. he can fight PREP person-other EMPH 'He can fight for someone else.'

(51) Xwla evi $O$ tEn nO fi xwesa xeO. child DET MOD stay here night this 'The boy may stay here tonight.'

(52) Xwla Jan tEn le OÙxweÚmE siÙEÚ.

Jean can COP house now

'Jean may be at home now.' 
The correspondences between the Gbe markers of possibility and $s a$ suggest that the latter may have been modeled on the former.

\subsection{Gbe influence on other aspects of possibility.}

In addition to $s a$, other devices used to express possibility in the Surinamese creoles also have counterparts in Gbe. For instance, like the creoles, several Gbe varieties (Aja, Xwela, Xwla) employ different auxiliaries to express possibility in negative contexts from those used in positive contexts. ${ }^{10}$

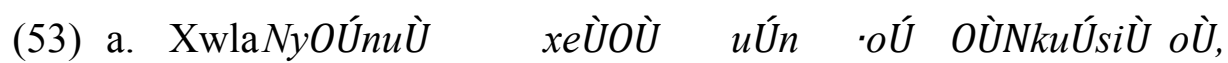
uÚn $\quad$ kpeÚ-ji ÚaÚ

woman DEM NEG have eye NEG NEG can FUT

kpOÚn miญ̀ oÙ.

see us NEG

'This woman is blind. She cannot see us.'

b. Xwela IviÚ 10Ú goÚ kpego laÚ nO xye ·eÚ hwedoÚ child DET NEG can FUT stay here LOC night eÙ.

NEG

'The child cannot stay here tonight.'

\footnotetext{
${ }^{10}$ Other Gbe varieties (Gen, Gun, Waci, Maxi) employ the same modal in
} both positive and negative contexts like Saamaka (cf. Migge 2006: 40ff). 
The auxiliaries used to express negative possibility derive from a construction expressing physical strength, or the sense of having achieved manhood (cf. Migge 2006: 49).
(54) Aja
$s E)-N u$
be hard/be strong-body
Xwla/Waci kpé-é-ji
reach-its-summit/top
Maxi kpé-e-ewu!
reach-its-body
'be strong' (Capo, p.c. 2003/Aboh p.c. 2004)

We suggest that the uses of man (in Sranan) and man and poy (in Pamaka and Ndyuka) were modelled on these modals (cf. Migge 2006).

Another similarity between the creoles and Gbe languages is that they all express epistemic possibility in negative contexts by means of a periphrastic construction translateable as 'it can be that.'

(55) a. Waci «Ú ti!NÚnyi! b«Ú Ko@fiÚ ýuさ̇-naÙ nu!

$$
\begin{aligned}
& c u ! s a) \text { Ú. } \\
& \text { it can COP that name eat-HAB thing all before } \\
& \text { 'It is possible that Kofi was greedy before' (Capo, p.c. }
\end{aligned}
$$


All of these similarities in the expression of possibility in Gbe and the Maroon creoles suggest that substrate influence played an important role in the emergence of this area of the creoles' grammar. The differences between Sranan and the Maroon creoles seem to be due to the fact that Dutch had stronger influence on the former, while Gbe had stronger influence on the latter.

\section{Conclusion.}

To sum up, the emergence and development of possibility in the Surinamese creoles followed quite different paths in Sranan as opposed to the Maroon creoles. A variety of factors contributed to these differences, the most significant of which appears to have been the degree to which Dutch as opposed to the Gbe languages influenced the respective creoles. The strong influence of Dutch in Sranan, evident even in the early texts, led to a system in which kan expressed most types of root possibility, supplemented by and mag for permission. Later internal developments, possibly aided by Gbe influence, led to the emergence of man as a marker of physical ability. Gbe influence on the Maroon creoles, on the other hand, led to a system in which all types of possibility were subsumed 
under the modal $s a$, which became a marker of Potential mood. Ndyuka and Pamaka also employed poy and man respectively, to express the sense of ability under negation. The use of $s a$ in the Maroon creoles contrasts strongly with its use in Sranan, where it conveys meanings quite similar to those of Dutch zullen. Finally, Gbe seems to have provided a model for other devices used to express epistemic possibility, such as the expression 'it can be that.'

Our study has shown that the grammars of the Surinamese creoles continued to evolve over time, in accordance with Arends' gradualist hypothesis. The combined effects of Superstrate and substrate influence, and internal factors, interacting with each other in different ways and at different times, all contributed to the creation and development of the grammar of possibility in the Surinamese creoles.

The changes that occurred in the systems of possibility over time present a challenge to any attempt to reconstruct the historical processes that led to the present state of affairs. Our investigation leaves many questions unanswered. For instance, what circumstances led to the more pervasive influence from Gbe languages on the Maroon creoles? Were there greater similarities between the earlier forms of Sranan and the earliest forms of the Maroon creoles? What similarities and differences were there between ningretongo and bakratongo, and how did each variety affect the later development of Sranan? What part did internal 
development, such as the emergence of future o, play in shaping the use of sa after the $18^{\text {th }}$ century? And finally, what light can the answers to all of these questions shed on the historical relationships among the creoles, and how each evolved in its own ecological setting? These are all important issues that future research will need to address. The present study, we hope, provides a foundation for such future investigation.

\section{References}

Arends, J. 1999. The origin of the Portuguese element in Surinam Creoles. In Spreading the Word, M. Huber and M. Parkvall (eds.), 195-208. London: Battlebridge.

Arend, J. 1995. Part I: The Sranan Texts. In Early creole texts : A collection of 18th-century Sranan and Saramaccan documents, J. Arends and M. Perl, 11-242. Frankfurt: Vervuert.

Arends, J. 1993. Towards a gradualist model of creolization. In Atlantic meets Pacific, F. Byrne and J. Holm (eds.), 371-380. Amsterdam: John Benjamins.

Arends, J. and A. Bruyn. 1995. Gradualist and developmental hypotheses. In Pidgins and Creoles: An introduction, J. Arends, P. Muysken, and N. Smith (eds.), 111-120. Amsterdam: John Benjamins.

Arends, J. and M. Perl. 1995. Early creole texts : A collection of 18thcentury Sranan and Saramaccan documents. Frankfurt: Vervuert. 
Arend, J. and Van den Berg. 2004. 'The Saramaka Peace Treaty in Sranan: An edition of the 1762 text (including a copy of the original manuscript). Creolica: Revue du Groupe Européen de Recherche en Langues Créoles (http://www.creolica.net).

Baker, P. 1995. Some developmental inferences from the historical studies of pidgins and creoles. In The early stages of creolization, J. Arends (ed.), 1-24. Amsterdam: John Benjamins.

Bruyn, A. 1995. Grammaticalization in Creoles: The development of determiners and relative clauses in Sranan. Amsterdam: IFOTT.

Bybee, J. L., Perkins, R. and W. Pagliuca. 1994. The evolution of grammar. Tense, aspect, and modality in the languages of the world. Chicago: The University of Chicago Press.

Coppen P.A., Haeseryn, W. and F. de Vriend. 2004. Elektronische Algemene Nederlandse Spraakkunst. Katholieke Universiteit Nijmegen (KUN). (http://www.let.ru.nl/ans/e-ans/)

Essegby, James. To appear. On why the a- morpheme is not a tense marker. In Aspect and Modality in Kwa languages, F. Ameka and M.E. Kropp Dakubu (eds), Amsterdam: John Benjamins.

Focke, H. C. 1855. Neger-Engelsch Woordenboek. Leiden. Van den Heuvell.

Huttar, G. and M. Huttar. 1994. Ndyuka. London: Routledge. 
Kramp, A. 1983. Early creole Lexicography : A Study of C.L Schumann's Manuscript Dictionnary of Sranan. Doctoral Dissertation, University of Leiden.

Migge, B. 2007. Codeswitching and Social Identities in the Eastern Maroon community of Suriname and French Guiana. Journal of Sociolinguistics 11(1): 53-72

Migge, B. 2006. Tracing the origin of modality in the creoles of Suriname. In Structure and variation in contact languages, A. Deumert and S. Durrleman-Tame (eds.), 29-59. Amsterdam: John Benjamins.

Migge. B. and L. Goury. 2006. Between contact and internal development: Towards a multi-layered explanation for the development of the TMA system in the creoles of Suriname. In Roots of Creole Structure, S. Michaelis (ed.), 301-331. John Benjamins, Amsterdam.

Palmer, F.R. 1986. Mood and modality. Cambridge: Cambridge University Press.

Rountree S. Catherine 1992 Saramaccan grammar sketch. Paramaribo: Summer Institute of Linguistics.

Smith, N. 1987. The Genesis of the creole Languages of Surinam. Doctoral dissertation, University of Amsterdam.

Schuchardt, H. (ed.) 1914. Die Sprache der Saramakkaneger in Surinam. Amsterdam: Johannes Müller. 
Singler, J. 1996. Theories of creole genesis, sociohistorical considerations, and the evaluation of evidence: The case of Haitian creole and the relexification Hypothesis. In Journal of Pidgin and creole Languages 11:185-230.

Singler, J. 1990. On the use of sociohistorical criteria in the comparison of creoles, In Linguistics 20:45-669.

Van den Berg, Margot. 2007. A Grammar of Early Sranan. Drukkerij Manta, Zetten,. Doctoral dissertation, University of Amsterdam.

Van den Berg, M. 2001. 'Mingo, joù no man'; Oud-Sranan in verhoren en verslagen van rechtszaken". Oso 20:241-253.

Van den Berg, M. 2000. “'Mi no sal tron tongo’: Early Sranan in court records, 1667-1767. MA theses, Katholieke Universiteit Nijmegen.

Van den Berg, M. and J. Arends. 2004. Court records as a source of authentic Early Sranan. In Creoles, contact and language change : Linguistics and social implication, G. Escure and A. Schwegler (eds.), 21-34. John Benjamins: Amsterdam.

van Dyk. n.d.[c1765] Nieuwe en nooit bevoorens geziene onderwyzinge in het Bastert Engels, of Neeger Engels, zoo als het zelve in de Hollandsze Colonien gebruikt word. Amsterdam: Jacobus van Egmont.

Voorhoeve, J. 1957. The verbal system of Sranan. Lingua 6: 374-96.

Wendelaar and Koefed 
Winford, D. 2000. Irrealis in Sranan: Mood and modality in a radical creole. Journal of Pidgin and creole languages 15 : 63-125.

Winford, D. to appear. Revisiting $s a$ and $o$ in Sranan. In Variation in the Caribbean. L. Hinricks and J. Farquharson (eds.). Amsterdam:

Benjamins.

Winford, D. and B. Migge. 2007. Substrate influence on the emergence of the TMA systems of the Surinamese creoles. Journal of Pidgin and creole languages 22(1): 73-99. 